\title{
Hepatocellular Carcinoma Pathologic TNM Finding v8
}

National Cancer Institute

\section{Source}

National Cancer Institute. Hepatocellular Carcinoma Pathologic TNM Finding v8. NCI Thesaurus. Code C134464.

A pathologic finding about one or more characteristics of hepatocellular carcinoma, following the rules of the TNM AJCC v8 classification system. 